\title{
THE IMPLEMENTATION OF THE RIGHT TO EDUCATION IN INDONESIA*
}

\author{
Munafrizal Manan ${ }^{* *}$ \\ * The earlier version of this article written while the author was studying at Universiteit Utrecht, The \\ Netherlands, 2013-2014. \\ ** Lecturer of human rights at Universitas Al-Azhar Indonesia.
}

\section{Article Info}

Received : 3 March 2015 | Received in revised form : 9 March 2015 | Accepted : 10 April 2015

Corresponding author's e-mail : munafrizal@uai.ac.id

\begin{abstract}
This article discusses the implementation of the right to education in Indonesia. It uses human rights and historical approaches. Human rights approach is used to describe international human rights instruments on the guarantee of the right to education that is applied universally. This approach is also dealing with international human rights instrument on the right to education that has been ratified by Indonesia as well as national regulation instruments on the right to education applied in Indonesia. Historical approach highlights the role of Indonesian governments in education sector after the Independence Day, especially regarding the implementation of the right to education. The discussion focuses on the development that has been achieved and the difficultythat has been faced in the implementation of the right to education. Despite there have been significant progresses achieved in implementing the right to education, the Indonesian governments remain facing the difficulty to fulfil the right to education for the entire of Indonesian citizens. However, in the middle of such a difficulty, it raises a creative idea and concrete action from civil society in terms of providing education service for marginalized and indigenous peoples.
\end{abstract}

Keywords: right to education, human rights, Indonesia, indigenous people, marginalized people

\begin{abstract}
Abstrak
Artikel ini membahas implementasi hak pendidikan (the right to education) di Indonesia. Pembahasan menggunakan pendekatan hak asasi manusia dan historis. Pendekatan hak asasi manusia memaparkan instrumen-instrumen hak asasi manusia internasional tentang jaminan hak pendidikan yang telah berlaku secara universal. Pemaparan juga dikaitkan dengan instrumen hak asasi manusia internasional tentang hak pendidikan yang telah diratifikasi oleh Indonesia serta instrumen regulasi nasional terkait dengan jaminan hak pendidikan yang berlakudi Indonesia. Pendekatan historis menyoroti peran pemerintahan-pemerintahan Indonesia dalam sektor pendidikan setelah Proklamasi Kemerdekaan, khususnya terkait dengan implementasi jaminan hak pendidikan. Pembahasan difokuskan pada perkembangan yang telah dicapai dan kesulitan yang dihadapi dalam implementasi hak pendidikan. Di samping ada kemajuan signifikan yang telah dicapai dalam impelementasi jaminan hak pendidikan, Indonesia masih menghadapi kesulitan memenuhi jaminan hak pendidikan untuk seluruh warga negara Indonesia. Namun, di tengah kesulitan yang dihadapi oleh pemerintah, muncul ide kreatif dan aksi konkret dari masyarakat sipil dalam bentuk memberikan pelayanan pendidikan bagi warga negara Indonesia yang hidup terpencil dan terpinggirkan.
\end{abstract}

Kata Kunci: hak pendidikan, hak asasi manusia, Indonesia, orang asli, orang pinggiran 


\section{Introduction}

The need for education is more than necessary. A global statesman like Nelson Mandela once said that "education is the most powerful weapon which you can use to change the world."No doubt that education is needed by all human beings.Without education, at least basic education, it is difficultfor people to participateactively in the globalization eraand reach opportunities provided by it.

Indonesia is no exception. From the very beginning of a newly independent state named the Republic of Indonesia was established following the Independence Proclamation on 17 August 1945, the State Founders were fully aware of the importance of the right to education. This was the reasonthey put the right to education into the Constitution of the Republic of Indonesia. For over six decades Indonesia has been struggling to provide educational services for the citizens. There are significant progresses today compared to six decades ago. However, Indonesia still faces difficulties to provide educational services for all citizens of Indonesia.

This present articleis an attempt to explore the implementation of the right to education in Indonesia by focusing on its developments and difficultiesover the last six decades. First, it provides a brief view on the right to education according to international human rights instruments some of which Indonesia has ratified. Next section describes the developments of the right to education in Indonesia. Then it identifies the difficultieswhichIndonesia facestofulfil the right to education especiallyfor the poor, marginalized and indigenous peoples. The final section concludes the whole of this article.

\section{The Right to Education in International Human Rights Instruments}

No dispute that the right to education is a universal right. It can be found in various international human rights instruments in terms of both declarations and agreements. It constitutes that the right to education is internationally recognized. First of all, the right to education is enshrined in the Universal Declaration of Human Rights (UDHR) of 1948. This is one of the most important international human rights instruments besides the International Covenant on Civil and Political Rights (ICCPR) of 1966 and the International Covenant on Economic, Social and Cultural Rights (ICESCR) of 1966, which are often called as the International Bills of Human Rights. Article 26 of the UDHR states that: ${ }^{1}$

1. Everyone has the right to education. Education shall be free, at least in the elementary and fundamental stages. Elementary education shall be compulsory. Technical and professional education shall be made generally available and higher education shall be equally accessible to all on the basis of merit.

2. Education shall be directed to the full development of the human personally and to the strengthening of respect for human rights and fundamental freedoms. It shall promote understanding, tolerance and friendship among all nations, racial or religious groups, and shall further the activities of the United Nations for the maintenance of peace.

3. Parents have a prior right to choose the kind of education that shall be given to their children.

${ }^{1}$ Sandy Ghandhi, Blackstone's International Human Rights Documents, $8^{\text {th }}$ ed., (Oxford: Oxford University Press, 2012), pp. 12-13. 
Although the UDHR is a charter-based human rights instrument which is not binding for the states, many other human rights instruments after the UDHR, both at international, regional and national level, refer to one or more of these provisions in formulating the right to education.

Another important international human rights instrument is the ICESCR. In a more detail, Article 13 of the ICESCR states that:

1. The States Parties to the present Covenant recognize the right of everyone to education. They agree that education shall be directed to the full development of the human personality and the sense of its dignity, and shall strengthen the respect for human rights and fundamental freedoms. They further agree that education shall enable all persons to participate effectively in a free society, promote understanding, tolerance and friendship among all nations and all racial, ethnic or religious groups, and further the activities of the United Nations for the maintenance of peace.

2. The States Parties to the present Covenant recognize that, with a view to achieving the full realization of this right:

(a) primary education shall be compulsory and available free to all;

(b) secondary education in its different forms, including technical and vocational secondary education, shall be made generally available and accessible to all by every appropriate means, and in particular by the progressive introduction of free education

(c) higher education shall be made equally accessible to all, on the basis of capacity, by every appropriate, and in particular by the progressive introduction of free education;

(d) fundamental education shall be encouraged or intensified as far as possible for those persons who have not received or completed the whole period of their primary education;

(e) the development of a system of schools at all levels shall be actively pursued, an adequate fellowship system shall be established, and the material conditions of teaching staff shall be continuously improved.

3. The States Parties to the present Covenant undertake to have respect for the liberty of parents and, when applicable, legal guardians to choose for their children schools, other than those established by the public authorities, which conform to such minimum educational standards as may be laid down or approved by the State and to ensure the religious and moral education of their children in conformity with their own convictions.

According to Klaus Dieter Beiter, "Article 13 may arguably be viewed as the most important formulation of the right to education in an international agreement." ${ }^{2}$ The ICESCR is a treaty-based human rights instrument that is binding to the ratified States Parties. It was adopted in 1966 and then came into force since 1976. As of April 2012, 160 states had ratified the ICESCR which shows that the vast majority of the UN member States is now the States Parties of the ICESCR. ${ }^{3}$ The States Parties

\footnotetext{
${ }^{2}$ Klaus Dieter Beiter, The Protection of the Right to Education by International Law: Including a Systematic Analysis of Article 13 of the International Covenant on Economic, Social and Cultural Rights(Leiden: MartinusNijhoff Publishers, 2006), p. 1.

${ }^{3}$ E. Riedel, "Economic, Social and Cultural Rights," inInternational Protection of Human Rights: A Textbook, $2^{\text {nd }}$ ed., editied by Catarina Krause and MartinScheinin, (Turku: ÅboAkademi University Institute for Human Rights, 2012), p. 131.
} 
have obligations to respect, protect andto fulfil economic, social and cultural rights including the right to education. They also must submit reports on the measures taken to implement the ICESCR.There is a monitoring body to supervise the implementation of the ICESCR by the States Parties. Under the Optional Protocol to the ICESCR of 2008 , it is possible to bring individual complaints of economic, social and cultural rights violations committed by the State Party to the Protocol to the Committee on Economic, Social and Cultural Rights. The Committee also has an authority to analyse the States Parties reports. With regard to the right to education, the Committee has issued several importantGeneral Comments,these of CESCR General Comment No. 11 on plans of actions for primary education, CESCR General Comment No. 13 on the right to education, and CESCR General Comment No. 3 on nature of State party's obligations. ${ }^{4}$

The right to education is also incorporated intoseveral international human rights instruments in order to protect the education right ofrefugees, women, child, migrants, disabled persons and indigenous peoples. They appear in Article 22 of the Convention Relating to the Status of Refugees (1951), Article 5(e) (v) of the International Convention on the Elimination of All Forms of Racial Discrimination (1966),Article 10 of the Convention on the Elimination of All Forms of Discrimination against Women (CEDAW) (1979), Article 5(2) of the Declaration on the Elimination of Discrimination based on Religion or Belief (1981), Article 28 and 29 of the United Nations Convention on the Right of the Child (CRC) (1989), Article 30, 43 and 45 of the International Convention on the Protection of the Rights of All Migrant Workers (1990), Article 24 of the Convention on the Rights of Person with Disabilities (CRPD) (2006), and Article 14 of the United Nations Declaration on the Rights of Indigenous Peoples (UNDRIP) (2007). ${ }^{5}$

Indonesia has ratified the international human rights instruments above. The ICESCR was ratified on 30 September 2005.0n 25 Mei 1999, the International Convention on the Elimination of All Forms of Racial Discrimination was ratified. The CEDAW was ratified on 13 September 1984. Also the CRC was ratified on 28 October 1998. The International Convention on the Protection of the Rights of All Migrant Workers was also ratified on 12 April 2012. Indonesia also has ratified the CRPD on 18 October 2011 and the UNDRIP on 13 September 2007.

All international human rights instruments aboveaffirm the importance of the right to education. It may be asked why the right to education is very important. TheCentre for Economic and Social Rightsexplains that:

Around the world, an estimated 855 million people, or one sixth of the world's population is illiterate. Millions of children never go to school. About 150 million, predominantly girls, are forced to drop out of school before they have achieved basic literacy and numeracy skills usually because their family is too poor to keep them in school. Education has been enshrined as a fundamental human right, essential for human dignity, but it is widely denied around the world. For many people, education remains a privilege rather than a right. The poor are excluded because they cannot pay. Yet without education, the poor will never escape poverty. ${ }^{6}$

\footnotetext{
${ }^{4}$ The Amnesty International, HakiZetu: ESC Rights in Practice, The Right to Education(Amsterdam: Amnesty International and ActionAid, 2012), p. 15.

${ }^{5}$ Ghandhi, op.cit., pp. 18, 28, 64, 74, 102, 131-134, 205, 231.

6 The Center for Economic and Social Rights, “Education,"http://cesr.org/section.php?id=9, accessed 13 January 2014.
} 
The answer of the above mentioned question can also be viewedin relation to the purpose of education. By taking the spirit of the UDHR and the ICESCR regarding the purpose of education, the importance of the right to education can be argued as follows:

With an educated population and a commitment to uphold human rights, a government is in a good position to avoid conflict and advance the country's development. Education is the primary tool for promoting human rights, equality and non-discrimination. It also promotes peace through increased understanding, tolerance, respect and friendship among different groups and cultures. It enables people to participate actively in society and in business, to create jobs, expand industry and raise living standards. ${ }^{7}$

The rightto education is not only "a matter of meeting basic human needs, developing human resources or achieving the objectives of socio-economic development," but also "a matter of observing rights protected by law.. ${ }^{8}$ Since the right to education is a human right that is formulated on the basis of law through international agreement or national constitution, a state has an obligation to comply with right to education. Thus, the failure to comply means the violation of international or national law. As education is human right and has legal status, statesareobligedto responsible. In the words of Beiter:

Access for all to free/affordable education of a high quality must then be assured by the state. The state will be the bearer of obligations with regard to education. A failure to comply with these obligations constitutes a human rights violation, for which the state is accountable. It will then be obliged to compensate victims and/or to secure that a failure does not happen again. ${ }^{9}$

There are three types of obligation on the States Parties to human rights (the right to education), these of the obligations to respect, to protect and to fulfil. The obligation to respect "requires States to abstain from performing, sponsoring or tolerating any practice, policy or legal measure violating the integrity of individuals or infringing upon their freedom to use those material or other resources available to them in ways they find most appropriate to satisfy" the right to education. The obligation to protect "requires the State and its agents to prevent the violation of any individual's rights by any other individual or non-State actor." Meanwhile, the obligation to fulfil "requires positive measures by the State when other measures have not succeeded in ensuring the full realization of these rights.. ${ }^{10}$

Furthermore, it is also probably asked what kind of education referred by international human rights instruments as mentioned above. Beiterobserved thatthe term of education used by international human rights instruments in general referring to formal institutional instruction. In this regard, the right to education in international human rights instruments is referred in its narrower sense. Thus, education deals with formal teaching and instruction provided by specialised institutions from primary,

\footnotetext{
${ }^{7}$ The Amnesty International, op.cit., p. 10.

${ }^{8}$ Beiter, op.cit., p. 2.

${ }^{9}$ Ibid., p. 3.

${ }^{10}$ Office of the High Commissioner for Human Rights, Economic, Social and Cultural Rights: Handbook for National Human Rights Institutions(New York: United Nations, 2005), pp. 15-18.
} 
secondary, to higher schools. ${ }^{11}$ The obligation of state to realise the right to education should therefore be viewed from this context.

In order to measure the application of the right to education by the state, there is a well-known concept namely "the 4 As" which means availability, accessibility, acceptability and adaptability.This concept was developed by former the UN Special Rapporteur on the Right to Education, Katarina Tomasevski, and then it was adopted in CESCR General Comment No. 13 paragraph 6.Based on this framework of "the 4 As", education must therefore be available, accessible, acceptable and adaptable for the people. The seriousness of the state to fulfil its obligation to the right to education can be assessed from this framework. ${ }^{12}$

\section{The Developments of the Right to Education in Indonesia}

The right to education has constitutionally been guaranteed by the Indonesian Constitution of 1945 (Undang-UndangDasarTahun 1945/UUD 1945)which was approved by the State Founders just one day after the Independence Proclamation proclaimed on 17 August 1945 or four years before the formal transfer of sovereignty from the Netherlands on 27 December 1949. When the State Founders drafted the Constitution for the newly Republic of Indonesia, they believed that "education would be the strategic vehicle for ensuring that the newly independent Indonesian nation would be modern, democratic, prosperous, and with a concept of social justice based on the state philosophy of [the so-called] Pancasila.. ${ }^{13}$

The importance of education has ideally been stated in the Preamble to the Constitution with the phrase of "to educate the life of the people." One of the main purposes of the establishment of the state is to achieve this ideal. Additionally, it has been stated in Article 31 of the Constitution that "[e]very citizen has the right to education." Additionally, Article 60 of the Law Number 39 of 1999 on Human Rights has stipulated that "every child has the right to access to education and schooling as befits his/her interests, talents, and intellectual capacity..

Furthermore, Indonesia had amended the Constitution four times including the provision on education from 1999 to 2002 respectively. As a consequence of the Fourth Amendment of the Constitution in 2002, there are now new Articles of Article 31 on education which among of them states that "[e]very citizen has the obligation to undertake basic obligation, and the government has the obligation to fund this," "the government shall manage and organise one system of national education," and "the state shall prioritise the budget for education to a minimum of $20 \%$ of the State Budget and of Regional Budgets to fulfil the needs of implementation of national education."

Perhaps "Indonesia is one of not so many nations whose constitution obliges the government to run one national educational system" and to allocate at least 20 per cent of national budget to education. ${ }^{14}$ It is interesting to note that most countries, even developed countries, do not mention explicitly the minimum percentage of

\footnotetext{
${ }^{11}$ Beiter, op.cit., p. 19.

12 Right to Education Project, "Education and the 4 As,"http://www.right-to-education.org/ node/226, accessed 15 January 2014. See also The Amnesty International, op.cit.,pp. 19-20.

${ }^{13}$ Soedijarto, "Some Notes on Ideals and Goals of Indonesia's National Education System and the Inconsistency of its Implementation: A Comparative Analysis,"Journal of Indonesian Social Sciences and HumanitiesVol. 2(2009):1.

${ }^{14}$ Ibid., p. 2.
} 
educational budget in their constitutions. Such constitutional guarantee is found only in a few countries, such as Brazil and Taiwan. The Constitution of Brazil states that educational sector budget shall be allocated 18 per cent for national level and 25 per cent for regional level of tax income. The Constitution of Taiwan states that at least 15 per cent shall be allocated to educational sector by the central government and 25 per cent by provincial governments. ${ }^{15}$

However,Tthere will be two dilemmatic consequences from suca constitutional guaranter. On the one hand, it must be fulfilled without considering the budget since fulfilling the allocation means obeying the constitution. On the other hand, it will put the state into "constitutional hostage" if the budget is unable to fulfil the allocation which means it disobeys the constitution. ${ }^{16}$ In addition, throughout Indonesian history there have been a series of education laws made to specifically regulate national education systemethey are education law of 1950, 1954, 1989, and 2003. Theseallshos that the importance of education is admitted at constitutional and statute level.

The State Founders were fully aware that one of the biggest challenges for Indonesia asa newly-established independent state was enormous educationalproblems. The priority was therefore given to education sector. As Justus M. Van Der Kroef pointed out, "[s]purred by nationalist ambitions to make Indonesia a strong modern state, the Indonesian government has made education one of the key objectives in its broad social welfare program.. ${ }^{17}$ One of the biggest problems faced bythe young Republic of Indonesiawas the massive illiteracy. Lawrence S. Finkelstein commented the factas follows:

After 300 years of Dutch rule, the new state of Indonesia is 80 percent illiterate. This simple fact poses one of the greatest challenges to the Indonesian government people. Four-fifths of the Indonesian people are illiterate. How is the newly independent state meeting the challenge of this enormous barrier to progress? ${ }^{18}$

Finkelstein also pointed out that "[i]lliteracy is only part of Indonesia's colonial legacy in the field of education." However, it does not mean that there was nochance at all for Indonesians to access education duringthat time. According to Finkelstein, "[u]nder Dutch rule, a fine European-style education was provided for a small minority of the Indonesian population" and "the tendency was for the privilege of education to be bestowed upon the predominant Indonesian royal and aristocrat families." ${ }^{19}$ The access to education was not for all Indonesians, it was only for a small group. Theywere "a privilege group" of "the intellectual and near-intellectual class of Indonesians" created by education ${ }^{20}$ and many of them were "the main motor behind the rise of the nationalist movement, leading to eventual independence."21 2005): 11

${ }^{15}$ MunafrizalManan, “Jaminan Konstitusional Anggaran Pendidikan,"Koran Tempo (9 November

${ }^{16}$ Ibid.

${ }^{17}$ Van Der Kroef,"Higher Education in Indonesia," The Journal of Higher EducationVol. 26 No. 7(October 1955): 366.

${ }^{18}$ L.S. Finkelstein, “Education in Indonesia,"Far Eastern SurveyVol. 20 No. 15(August 1951): 149. It should be added here that there is a different estimation of the number of illiteracy in Indonesia during that time. Instead of $80 \%$ illiteracy as Finkelstein mentioned, other sources believe that it was probably $90 \%$ or $95 \%$ illiteracy.

${ }^{19}$ Ibid. 1955):: 42-43.

20 Wertheim, “Changes in Indonesia's Social Stratification,"Pacific AffairsVol. 28 No. 1 (March

${ }^{21}$ MarteenKuitenbrouwer, "Colonialism and Human Rights: Indonesia and the Netherlands in Comparative Perspective,"Netherlands Quarterly of Human RightsVol. 21No.2(2003): 223. 
The Indonesian government of the newly independent state had immediately faced the fact that there wereabout 56 to 60 million Indonesianswho were not able toread or write. ${ }^{22}$ Faced with such a deficiency, there was no choice but to put education as one of the priorities into development programmes. As Finkelsteinhas revealed:

To meet these deficiencies, the Indonesian government has started a large-scale adult education program, designed to defeat illiteracy over a ten-year period. Grade and high school facilities are being expanded, teachers' training accelerated, and university capacity developed. New universities are being opened and education at a higher level will be available in Sumatra and other parts of Indonesia where such facilities have never before existed. ${ }^{23}$

Nevertheless, it was not an easy task to accelerate the educational programmesdue to limited budget, lack of lecturers, poor infrastructure and facility, incomplete curriculum,old cultural barrier, and so forth.This was the reason whythe programme was designed not too ambitious. In adult education programme, for example, it was expected that an extensive literacy campaign would produce two million new literates per year over a ten-year period. ${ }^{24}$ Within the next ten years it was estimated there would be 20 million new literates out of 50 million illiterates. In fact, it was difficultto achieve this expectation. A longer time and all relevant necessary resources were needed to eliminate the illiteracy totally. Again,Finkelstein described well such a difficulty as follows:

Even to appreciate the magnitude of the task is an exercise in imagination. More than 50 million people need to be educated. They are scattered over all the Indonesian islands, three thousand miles of them. Communications are poor-in some areas the roads will not sustain to carry children to school. Paper is in very short supply. Textbooks are almost non-existent, and few could afford to buy them if they were available. Qualified teachers are few. And to complicated matters, it is not even feasible to use a single language of instruction, for Indonesians speak a bewildering variety of dialects-Javanese, Sundanese, Madurese, Minangkabau, Balinese, Ambonese, etc. ${ }^{25}$

The Indonesian leaders including President Sukarno during the so-called the Old Order era believed in the importance of education for the country. There was a political will of the government to develop education sector. However, their efforts had unexpectedly been interrupted by national criticalsituations during that time in terms of independence revolution, political instability, national disintegration, political confrontation and economic problem.As a result, the governments could not fully concentrateto successfully implement the educational programmes and wasnot possible to do something more progressive for education sector. Although the results of the programme were not too success, the condition has changed gradually. It is therefore the task of the next government to pay a more serious attention to education.

It was during the New Order's government Indonesia had a better chance to acceleratethe development of education sector. This was a period where national political stability could be well-preserved for economic development means. The political system in this periodwas authoritarian that gave the government had a strong position to govern.

\footnotetext{
${ }^{22}$ Finkelstein, loc.cit.

${ }^{23}$ Ibid., p. 150.

${ }^{24}$ Ibid., p. 151

${ }^{25}$ Ibid.
} 
As the previous government,the next government in the so-called the New Order era was also obliged by the Constitution and Laws to develop education sector. However, the condition of national education sector itself was still underdeveloped at that time. The number of illiteracy was still high, as well as educational human resources, school facilities and infrastructures were limited. Moreover, education was needed to produce many more educated and highly skill workers to develop and modernizethe country.

When the first time the New Order's government under President Soehartotook over the power from President Sukarno in 1966, the Government inheritedthedomestic economic breakdown from the previous government. The inflation rate was extremely high, $650 \%$ per year. ${ }^{26}$ This was why the fundamental mission of the New Order government was to recover and grow economy as well as at the same time to stabilize politicswhich was needed to support the mission. Contrary to the economic policy of the President Sukarno, the new government,with the support of the economic technocrats, had "adopted a pragmatic, non-ideological approach and entrusted economic policy making" that "allowed the new government to implement various economic policies which in fundamental ways differed from the former government."27 The results of this economic policy were remarkable and tangible. In general, the inflation rate was low, the economic growth was high enough and the money to build infrastructure and social development, including education, was relatively available.

With regard to education sector, the New Order regime had expansively multiplied the number of primary schools. The focus was establishing elementary schools in almost every village across the country. Moreover, to fill the need of teachers for the schools, the government had massively recruited new teachers although not all of them had a good quality to become teacher ${ }^{28}$ The illiteracy, for example, reduced significantly. A data from the World Bank compiled by Thee KianWie shows that in the beginning of the New Order government adult literacy was only 47\% (male and female). At the end of the New Order government, which was about thirty years later, the literacy had massively soared to $90 \%$ for male and $78 \%$ for female. ${ }^{29}$ Wie illustrates well the education developmentduring the New Order era as follows:

In education the Indonesian government used some of the windfall oil tax revenues to expand education, particularly in rural primary schools (Jones 1994: 164). Universal primary education was achieved in the 1980s, assisted by slower growth of the primary school age population due to the successful family planning program. In turn this necessitated expansion of high school, vocational and tertiary education to meet the needs of the booming manufacturing and construction industries (Jones 1994: 165). Given that the New Order government began with such a low level of enrolments, its achievements in expanding primary education may be seen asbetter than those of Malaysia, the Philippines and Thailand, and comparable to those of South Korea. However, expansion of secondary and tertiary education has lagged

${ }^{26}$ BBC Indonesia, “Ekonomi di bawahOrdeBaru,"http://www.bbc.co.uk/indonesian/indepth/story/2008/01/080127_suhartoeconomy.shtml, accessed 18 January 2014.

${ }^{27}$ Thee KianWie, “The Soeharto Era and After: Stability, Development and Crisis, 1966-2000," in The Emergence of A National Economy: An Economic History of Indonesia, 1800-2000 (Sydney: Allend\&Unwin, 2002), p. 203.

28 AnisBaswedan, "Higher Education as an Instrument for Structural Changes in Indonesia,"(presented for USINDO Open Forum Brief, 16 March 2012), http://www.usindo.org/resources/ higher-education-as-an-instrument-for-structural-change-in-indonesia, accessed 17 January 2014.

${ }^{29}$ Wie, op.cit., p. 202. 
behind most neighbouring countries. Standardsof adult literacy among both men and women are lower than in other countries in the region (with the exception of Malaysia). ${ }^{30}$

In short, the New Order government had made notable achievements in education sector compared to the previous government, although this does not mean that the problems had entirely been resolved. The New Order government had prioritized education sector as one of its developmental programmes and as a result it had opened access to education for many Indonesians. However, it should be noted that the politics of education of the government was by design directed to merely supporteconomic development. Thus, the development of education should be understood as an effort to run economic growth rather than to develop the quality of education itself. Singgih Tri Sulistiyonoillustrates such a reality as follows:

Education development projects were even functioned to support the success of economic development. This gave significant impact to the development of education sector. Rapid expansion of capacity was not only occurred at elementary and secondary school levels but also at higher education one. Higher education enrolments peaked during the 1970s and 1980s. This development stimulated the establishment of new higher education institutions by private initiatives which mostly without sufficient capability to conduct qualified education. Most private higher education institutions only benefited the opportunity to respond the demand of higher education. Most students entered to private universities after failing to access public universities. This explains the rapid development of private universities in Indonesia. ${ }^{31}$

The New Order regime had centralized education management and allowed only limited higher education autonomy and academic freedom. The reason was "the government did not want to give broader autonomy to the higher education institutions" because "[a]n extensive autonomy might be viewed as a potential to be in opposition to the centralistic government." ${ }^{32}$ Indeed, Indonesian history shows that higher education institutions are the source of criticism to the power.

Following the fall of President Soeharto on 21 May 1998, Indonesia entered the era of reformation in which Indonesian politics has changed dramatically. Along with this, there was also the agenda of education reform though it is not a kind of dramatic change as in politics. The most important one was the amendment the Indonesian Constitution of 1945 regarding education as has been mentioned earlier. This amendment strengthens the obligation of the state to fulfil the right to education. It was then followed by the Law Number 20 Year 2003 to guiding the application of national education system. In addition, based on the Government Regulation Number 61 Year 1999 regardingPerguruanTinggiBadanHukumMilikNegara (PTBHMN/Higher Education of State-Owned Legal Entity), the government had allowed autonomy and self-governance toinitially several public universities. It must be noted that this policy was not only meant to reduce the centralisation of the government, but also to decrease the obligation of the state to finance education sector since the budgetary capacity of the state was decreasing. The side effect of such apolicy was

\footnotetext{
${ }^{30}$ Ibid., p. 201.

${ }^{31}$ Singgih Tri Sulistiyono, "Higher Education Reform in Indonesia at Crossroad,"(paper presented at the Graduate School of Education and Human Development, Nagoya University, Japan, 26 July 2007), p. 6, <www.dikti.go.id/files/atur/bhp/HEReform-Singgih.doc, accessed 17 January 2014.

${ }^{32}$ Ibid., p. 8.
} 
the marketization and commercialization of education. It then was rejected by the public because such a less populist policywould close the opportunity of the poor to access education in public universities. Some argue that "the government's reform on education seems to be used as the way for avoiding financial responsibility." ${ }^{33}$

On the other hand, there was also fruitful educational programme made by the government to fulfil the right to education. The government launched the Nine-Year Compulsory Basic Education Program for every citizen aged 7-15 years. They are obligated to enrol in the elementary and junior high schools.At the World Education Forum in 2000 Indonesia made a commitment to achieve Basic Education for All (EFA). It is claimed by the government that Indonesia has accomplished the target of the Nine-Year Compulsory Basic Education Program in 2008, which was seven years earlier than the EFA's. ${ }^{34}$ Additionally, the success of the Nine-Year Compulsory Basic Education Program has motivated the government to launch the Twelve Years Universal Education Program, popularly known PendidikanMenengah Universal (PMU), extending the duration of compulsory education from nine years to twelve years. As the Minister of Education and Culture Mohammad Nuhexplained:

PMU program is one strategy for dealing with the growing population of productive age in Indonesia. Through the PMU program, the government will provide greater opportunities for every citizen to participate in a quality secondary education by facilitating the population aged 16-18 years in order to attend secondary education. The program is currently under an implementation trial in the academic year 20122013 with a limited coverage and it will be accompanied with full budget support from the academic year of 2013-2014 onward. PMU policy is believed to accelerate the increase in the gross enrolment ratio (GER) in senior high secondary schools, which has recently reached $78.7 \%$ to around $97 \%$ by 2020. Which, if the acceleration efforts were not made, achievements APK [AngkaPartisipasiKasar/the gross enrolment ratio] $97 \%$ is expected to be achieved by $2040 .^{35}$

Theattention must also be given to other different portrait of Indonesian education. For example, the rate of the drop out of school is still high. Mostly they come from the poor people whose parents not able to fund their advanced education. As Baswedan found:

Today there are 165,000 elementary schools but only 43,000 junior high schools and just over 25,000 high schools. Thus it is clear that not everyone will have access to secondary education. For example, every year 5.3 million Indonesians enter first grade but only 2.2 million students will graduate from high school. Thus 3.1 million students per year drop out of school before reaching high school. ${ }^{36}$

Moreover, adata published by the Ministry of National Education noted that during the school years of 2004/2005 and 2005/2006 junior high school students who discontinued their study was 148,980 students or $1.97 \%$ and elementary school students was 824,684 students or $3.17 \%$ nationally. It was predominantly because

${ }^{33}$ Ibid., p. 14 .

${ }^{34}$ Suyanto, "Kebijakan Pemerintah tentang Pelaksanaan Hak atas Pendidikan Dasar di Indonesia, "http://dikdas.kemdikbud.go.id/application/media/file/PAPARAN\%20DI\%20KEMKUMHAM\%20 081110.pdf, accessed 16 January 2014).

35 Antara News, "Indonesian Government Launches Twelve Years Universal Education Program,"http://www.antaranews.com/en/news/89553/indonesian-government-launches-twelveyears-universal-education-program, accessed 17 January 2014.

${ }^{36}$ Baswedan, loc.cit. 
their parents could not afford the cost for education. ${ }^{37}$

To cope with the problem above, in July 2005, the government launched the socalled BantuanOperasionalSekolah/BOS (School Operational Assistance) programme to reduce the attrition rate at the elementary and junior high school levels. To implement theBOS programme, the government initially budgeted Rp10.3 trillion and it then increased to RP 11.2 trillion in 2006. In 2010, the amount reached Rp16 trillion, or $7.5 \%$ of Rp224 trillion of the total national education budgets (20\% of the national budget). Although the BOS funds are not sufficient to cover the whole operational expenses of the school, it at least shows that the government strongly supports the implementation of the Nine-Year Compulsory Basic Education program. ${ }^{38}$ Moreover, the government provides the scholarship for the poor students. In 2010, the total budget of Rp808,848,000,000 was allocated for 2.246 .800 elementary school students and Rp457,156,150,000 for 831,193 lower middle school students. Every elementary school student accepts Rp360,000 per year, while every lower middle school accepts Rp550,000 per year. ${ }^{39}$

Actually, the government could have done more to escalate the progress of education sector so that the right to education could be enjoyed by all Indonesians. However, there has been no serious political will from the political elites in the government as well the parliament to allocate more budgets for education sector. An Indonesian Professor of Education, Soedijarto, has critically argued that" $\mathrm{t}] \mathrm{he}$ problem that Indonesia faces is that budget allocations for education have never been adequate to provide educational resources to enable the education system to produce the outcomes it could and should." 40 In 2004, for example, an official data published jointly by Statistic Indonesia, the National Development Planning Agency of Indonesia and the United Nations Development Programme Indonesia reported that "Indonesia spends around $1.5 \%$ of GDP on education, a proportion far lower than that in many Asian countries" such as India (5.2\% of GDP), Malaysia (5.2\% of GDP), Thailand (5.0\% of GDP), Vietnam (2.8\% of GDP), the Philippines (3.4\% of GDP), South Korea (5.3\% of GDP) and Japan (7\% of GDP). ${ }^{41}$

As has been mentioned earlier,under the amended Indonesian Constitution of 1945 the state has an obligation to allocate at least $20 \%$ of the national budget and of regional budget for funding the education sector. However, it has not been applied by the government and the parliament until the Indonesian Constitutional Court issued a judicial review verdict in 2009 that stating the government and the parliament must fulfil the obligation as it is ordered by the Constitution. Apparently, both the government and the parliament were not happy with the Constitutional Court's verdict, but to avoid political risky and public anger they accepted it. On the paper,the allocation of 20 per cent of the national budget for education has been planned. In practice, however, the allocation is not for the implementation of the education system as it is hoped because the allocation is also including for teacher's salaries. As Soedijarto noted, "[t]he portion for the implementation of the education system is about Rp80

${ }^{37}$ F. W. Handoyo, "Evaluation of the Impact of the School Operational Assistance Program Implementation: Data Analysis of the Indonesian Family Life Survey, Years 2000 and 2007," The SMERU Research Institute NewsletterNo. 33(December2012): 24-25.

${ }^{38}$ Ibid.

${ }^{39}$ Suyanto, loc.cit.

${ }^{40}$ Soedijarto, op.cit., p. 4.

${ }^{41}$ Ibid., p. 5. 
trillion, about 8 per cent of national budget, still less than 2 per cent of GDP."42

Obviously, the political elites do not seriously and consistently obey the Constitution regarding education. They reluctant to support the education sector as the State Founders did. Perhaps, they do not view education as a long term investment toimprove human resources and to build the country. Thus, one of the current obstacles of Indonesian education sector is politics. In the words of Soedijarto:

[T]here has been no serious political determination on the part of the elites who control government and parliament to support the implementation of an education system that accords with the hopes and ambition of the Founding Fathers[and as a result] Indonesia's development in economics, science and technology is still behind neighbouring countries that became independent decades after Indonesia. ${ }^{43}$

Corruption in the education sector also needs to be taken as another factor that influences the full implementation of the right to education in Indonesia. It is wellknown that the education sector is one of the most corrupt sectors in Indonesia. The Indonesian Corruption Eradication Commission (KomisiPemberantasanKorupsi: KPK) has been prosecuting the cases of corruption within the education sector. The KPK revealed that from 2003 to 2013 there were 296 corruption cases with 479 corruption suspects which was detrimental to Rp 619 billion of the education sector budget. ${ }^{44}$ The KPK identified two forms of corruption of these cases, these of the misallocation of BantuanOperasionalSekolah(BOS/School Operational Assistance) programmeand the gratification ofTunjanganProfesi Guru (Teacher Professional Allowance) ${ }^{45}$ With regard to the corruption within the education sector, a research conducted by Daniel Suryadarma finds that corruption affects the relationship between public spending on education and education outcomes in Indonesia. Suryadarmameasures the effect of public spending on school net enrolment rates and school performance in national examinations. He notes that there are two forms of corruption in the education sector, these of embezzlement of education program funds and high teacher absence. ${ }^{46}$ Obviously, corruption in the education sector affects the progressive realization of the right to education in Indonesia and the principal victims of the corruption are the peoples.

\section{The Right to Education for Marginalized and Indigenous Peoples}

Although Indonesia has paid attention to the right to education throughout its post-independence history, in terms of legal framework, infrastructure and facilities, in fact there are stilldifficulties to fulfil the right to education for all Indonesians across the country.Indeed, it is not an easy task to successfully implement the right to education for a country like Indonesia that has 237.641 .326 inhabitants, ${ }^{47} 365$ ethnic and tribal groups, 500 local languages and dialects as well as is divided by 33

\footnotetext{
${ }^{42}$ Ibid.

${ }^{43}$ Ibid.,pp. 1-2.

${ }^{44}$ AntaraNews, “KPK PetakanPolaKorupsidalam Dana Pendidikan,”http://www.antaranews.com/ berita/451589/kpk-petakan-pola-korupsi-dalam-dana-pendidikan, accessed 14 January 2015.

${ }^{45}$ Ibid.

${ }^{46}$ D. Suryadarma, "How Corruption Diminishes the Effectiveness of Public Spending on Education in Indonesia,"Bulletin of Indonesian Economic StudiesVol. 48 No. 1 (2012): 85.

47 This population number is based on the latest official population census conducted by Statistic Indonesia in 2010, http://bps.go.id/tab_sub/view.php?kat=1\&tabel=1\&daftar=1\&id_subyek=12\&notab=1, accessed 13 January 2014.
} 
provinces and 13.466 islands across the country. Under these circumstances, even though the governments have made the programmes and allocated the budget for educationalservices, there are still Indonesians who have a limited access to education and do not have adequate school infrastructures, especially the poor, marginalized and indigenous peoples.

The government is still not able to provide educational services equally for all Indonesians throughout the country. While Indonesia has significantly achieved the basic education program for all, the illiteracy has not totally been eradicated yet. In 2010,the illiteracy rate was $6 \% \cdot{ }^{48}$ Moreover, thedistribution of universities in Indonesia is not equitable, they are mostly in Java. In Jakarta and West Java, for instance, there are 790 universities; where Jakarta itself has over 300 higher education institutions. ${ }^{49}$ It indicates that the right to education is not enjoyed by all Indonesians across the archipelago.Such a condition is confirmed by a report submitted by the Special Rapporteur of the United Nations Commission on Human Rights regarding the right to education in Indonesia which noted that:

Nine years of compulsory education for all are planned by the year 2009 or 2010. Making sure that all children attend junior secondary school is particularly difficult because it costs three times as much as primary school. Junior secondary schools still cannot accommodate all children, particularly in rural and isolated areas. ${ }^{50}$

In addition, the country is still struggling to cope with the problems of education for children with special needs including the mentally retarded. Children with special needs (the difable) are still marginalized and excluded to access regular school. They are mostly only able to access special education that has been established by the government such as Special Schools (SekolahLuarBiasa/SLB), Special Elementary School (SekolahDasarLuarBiasa/SDLB), and Special Secondary School (SekolahMenengahLuarBiasa/SMLB). As FawziaAswinHadishas observed:

Up to the present time, most of the children with special needs, such as the blind, the deaf, the mentally retarded, and the physically handicapped are still enrolled in special schools for each disability (SLB), or in special schools for several disabilities (SDLB). Only a very small number of regular schools are willing to admit children with special needs. Even this view, are only willing to accept blind, deaf and the autistic children who are without any intellectual disorder. Their refusal to admit mentally retarded children is the cause that children with this disability are still enrolled in special schools (SLB or SDLB). ${ }^{51}$

According to Hadis, this is due to several reasons, namely, "the number of special schools are very limited and mostly are located in the capital city of regencies," "the cost of sending children to special schools is higher than sending them to regular school," and "[m] ost of special schools are private schools" and "expensive compared

${ }^{48}$ Baswedan, loc.cit.

${ }^{49}$ Ibid.

${ }^{50}$ Katarina Tomaševski“Economic, Social and Cultural Rights, the Right to Education,"(a Special Rapporteursubmitted to Commission on Human Rightsin accordance with Commission resolution 2002/23, Addendum, Mission to Indonesia, 1-7 July 2002, E/CN.4/2003/9/Add.1, 14 November 2002), p. 8.

${ }^{51}$ F. A. Hadis,", Toward Inclusive, Inclusive Education in Indonesia: A Country Report,”(paper presented at Seisa University, Ashibetsu-shi, Hokkaido, Japan, 9 July 2005)http://rikorea.freeget.net/naraboard/db/data03/upload/128773804685.0.6-Toward_InclusiveInclusive_Educa-Indonesia-Co.pdf, accessed 15 January 2014. 
to governmental regular schools." ${ }^{52}$ While the solution from the government cannot be expected, several regions initiatedwith their own effort to provide inclusive education in their regular schools. In GunungKidul, Yogyakarta Province, inclusive education has been implemented since 2001 in 12 schools, and then 2 schools admitted mentally retarded children. It has also been implemented in DKI Jakarta Province in 35 schools and 5 regular elementary schools are chosen as models for inclusive education. ${ }^{53}$

The absence of the government in the grass root educationsectorhas stimulated initiative from civil society to take a constructive role. In this connection, two other cases namely IndonesiaMengajar(Indonesia Teaches) and SokolaRimba (the Jungle School)are also interesting to view. These two cases also suggest that in reality the government is not able to do everything for education, and thereforethe non-state actors should do something for education.Indeed, the government must responsible for education service, but the society should take an action while the government absent from it. Otherwise, the society will not have an opportunity to access education or to improve the quality of education.

The movement of Indonesia Mengajaris designed for marginalized people in Indonesia, while SokolaRimba is aimed for indigenous people. The former is useful for a country like Indonesia where there are still numerousschools which do not have sufficient facilities such as teachers, books and other learning instruments. While the latter is also valuable for a country like Indonesia that has 208,277 indigenous ethnic group population or $1,041,000$ peoples disseminated in 18 provinces, particularly in hinterlands and remote islands. ${ }^{54}$

Indonesia Mengajar is an educational movement initiated by AniesBaswedan, an Indonesian education practitionerwho graduated PhD from the USA.It has been sending the best fresh graduates to remotevillages and hinterlands in Indonesia for teaching one year in elementary schools. The mission of the movement is to fill the lack of qualified elementary school teachers in the regions of Indonesia. One of the big problems of Indonesian education is the lack of qualified teachers. In 2009, there were $75 \%$ teachers who didnot hold bachelor background and another $75 \%$ teachers would be retired. ${ }^{55}$ Moreover, the distribution of teachers itself is not equitable. There are $21 \%$ schools in urban areas lack of teachers, while $37 \%$ schools in villages and $66 \%$ in remote areas. ${ }^{56}$ The movement has been started since 2009 and sponsored by big corporations and supported by the Ministry of National Education, partners and donators.From 2010 to 2012, Indonesia Mengajar has sent 361 educated young shortterm teachers chosen from 40,194 applicants ${ }^{57}$ to 17 regencies in 16 provinces across the archipelago; they are Provinces of Aceh, Riau, South Sumatera, Lampung, Banten, East Java, West Kalimantan, East Kalimantan, North Sulawesi, Southeast Sulawesi, West Sulawesi, West Nusa Tenggara, East Nusa Tenggara, Maluku, North Maluku and

\section{Ibid.}

53 Ibid.

${ }^{54}$ D. Saripudin, "Non Formal Education for Indigenous Community in Indonesia: An Initial Review,"International Journal of Learner DiversityVol. 2No. 1(December 2009): 35, accessed 15 January 2014,http://file.upi.edu/Direktori/FPIPS/JUR._PEND._SEJARAH/197005061997021-DIDIN_SARIPUDIN/ Artikel_Jurnal/IJDL_2009.pdf.

${ }^{55}$ Indonesia Mengajar, “Tentang Indonesia Mengajar," https://indonesiamengajar.org/faq/, accessed on 19 January 2014.

56 Ibid.

57 Tempo News, "AniesBaswedan: 'Indonesia Mengajar' TidakPolitis, "http://www.tempo.co/ $\mathrm{read} / \mathrm{news} / 2013 / 09 / 26 / 078516917 /$ Anies-Baswedan-Indonesia-Mengajar-Tidak-Politis, accessed 19 January 2014. 
Papua. ${ }^{58}$ These young short-term teachers are recruited tightly and competitively from the best university graduates and then trained before sent to the remote locations. This movement has contributed providing the availability of qualified teachers for elementary school pupils.

Another interesting case is SokolaRimba, a movement initiated by ButetManurung, an Indonesian activist who holds a Master of Anthropology from Australia. This movement has been started since 1999 and was initially initiated for the Orang Rimba (the jungle people), a nomadic tribe who live in the rainforests of Jambi Province in Sumatera island. Mostly they were illiterate. Manurung came to their place and lived with them for a few years to persuade their interest to learning reading and writing. After having succeeded in this area, she then expands to other isolated areas. Since 2003, SokolaRimba made the same program in 8 different provinces across the archipelago, which has benefited over 10,000 children and adults in isolated indigenous communities. ${ }^{59}$ The areas that have been touched are in Mariso district (Makasar) where almost $80 \%$ population was illiterate, in Wallago (Flores) where almost the entire community was illiterate, in the Tidore Archipelago (Halmahera), in the district of Kajang (Bulukumba), and in Mumugu Batas Batu Village (Papua) where more than $97 \%$ of the people are illiterate. ${ }^{60}$ This movement has also contributed giving an access to basic education for the indigenous communities across the archipelago.

\section{Conclusion}

This article has described and discussed the developments and difficulties of the implementation of the right to education in Indonesia. Indonesia has admitted the importance of the right to education as shown by the adoption of the right to education into the Constitution and Statutes and the ratification of international human rights instruments as well as creating education programme projects by the government. In a considerable degree, the results over the last six decades are concrete. The illiteracy rate was decreased drastically and the school infrastructures have been built, for instance. However, the government has a limited capability, and to a certain extent lack of a serious political will, to work more progressively to fulfil the right to education as well as to improve the quality of education for all Indonesian across the archipelago, especially for the poor, marginalized and indigenous peoples in remote areas. In response to this, civil society has been taking constructive efforts to fill the role left by the government. To be sure, Indonesia still needs to work harderin order to develop more the education sector and to cope with the difficulties. It is therefore hoped that the new Government of President JokoWidodo would be able to fulfil the right to education for all Indonesians as well as accelerate the development of education sector.

\footnotetext{
${ }^{58}$ Indonesia Mengajar, loc.cit.

${ }^{59}$ SokolaRimba, "Program," http://www.sokola.org/program/, accessed 19 January 2014.

${ }^{60}$ Ibid..
} 


\section{Bibliography}

\section{Books}

Baswedan, Anis. "Higher Education as an Instrument for Structural Changes in Indonesia."Presented for USINDO Open Forum Brief. 16 March 2012. http:// www.usindo.org/resources/higher-education-as-an-instrument-forstructural-change-in-indonesia. Accessed 17 January 2014.

Beiter, Klaus Dieter. The Protection of the Right to Education by International Law: Including a Systematic Analysis of Article 13 of the International Covenant on Economic, Social and Cultural Rights. Leiden: MartinusNijhoff Publishers, 2006.

Ghandhi, Sandy.Blackstone's International Human Rights Documents. $8^{\text {th }}$ ed. Oxford: Oxford University Press, 2012.

Office of the High Commissioner for Human Rights.Economic, Social and Cultural Rights: Handbook for National Human Rights Institutions. New York: United Nations, 2005.

Riedel, E. "Economic, Social and Cultural Rights," in International Protection of Human Rights: A Textbook. $2^{\text {nd }}$ ed. Editied by Catarina Krause and Martin Scheinin. Turku: ÅboAkademi University Institute for Human Rights, 2012.The Amnesty International.HakiZetu: ESC Rights in Practice, The Right to Education. Amsterdam: Amnesty International and ActionAid, 2012.

Wie, Thee Kian. "The Soeharto Era and After: Stability, Development and Crisis, 1966-2000," in The Emergence of A National Economy: An Economic History of Indonesia, 1800-2000. Sydney: Allend\&Unwin, 2002.

\section{Articles}

Finkelstein, L.S. "Education in Indonesia." Far Eastern SurveyVol. 20 No. 15 (August 1951) : 149-153.Handoyo. F. W. "Evaluation of the Impact of the School Operational Assistance Program Implementation: Data Analysis of the Indonesian Family Life Survey, Years 2000 and 2007." The SMERU Research Institute NewsletterNo. 33 (December 2012).

Kroef, Van Der. "Higher Education in Indonesia." The Journal of Higher EducationVol. 26 No. 7 (October 1955): 366-377.Kuitenbrouwer, Marteen. "Colonialism and Human Rights: Indonesia and the Netherlands in Comparative Perspective." Netherlands Quarterly of Human RightsVol. 21No.2 (2003): 203-224.

Manan, Munafrizal. "JaminanKonstitusionalAnggaranPendidikan.” Koran Tempo. (9 November 2005): 11.

Saripudin, D. "Non Formal Education for Indigenous Community in Indonesia: An Initial Review." International Journal of Learner DiversityVol. 2 No. 1 (December 2009): 35. Accessed 15 January 2014. http://file.upi.edu/Direktori/FPIPS/ JUR._PEND._SEJARAH/197005061997021-DIDIN_SARIPUDIN/Artikel_Jurnal/ IJDL_2009.pdf.

Soedijarto. "Some Notes on Ideals and Goals of Indonesia's National Education System and the Inconsistency of its Implementation: A Comparative Analysis." Journal of Indonesian Social Sciences and HumanitiesVol. 2 (2009): 1-11.Suryadarma, D. "How Corruption Diminishes the Effectiveness of Public Spending on Education in Indonesia." Bulletin of Indonesian Economic StudiesVol. 48 No. 1 (2012): 85100.

Sulistiyono, Singgih Tri. "Higher Education Reform in Indonesia at Crossroad." Paper presented at the Graduate School of Education and Human Development, Nagoya University. Japan, 26 July 2007. www.dikti.go.id/files/atur/bhp/ HEReform-Singgih.doc. Accessed 17 January 2014. 
Tomaševski, Katarina. “Economic, Social and Cultural Rights, the Right to Education.” A Special Rapporteur submitted to Commission on Human Rightsin accordance with Commission resolution 2002/23, Addendum, Mission to Indonesia, 1-7 July 2002, E/CN.4/2003/9/Add.1, 14 November 2002.

Wertheim."Changes in Indonesia's Social Stratification."Pacific AffairsVol. 28 No. 1 (March 1955):.41-52.

\section{Websites}

Antara News. "Indonesian Government Launches Twelve Years Universal Education Program." http://www.antaranews.com/en/news/89553/indonesiangovernment-launches-twelve-years-universal-education-program.Accessed 17 January 2014.

Antara News. "KPK PetakanPolaKorupsidalam Dana Pendidikan." http://www. antaranews.com/berita/451589/kpk-petakan-pola-korupsi-dalam-danapendidikan.Accessed 14 January 2015.

BBC Indonesia. "Ekonomi di bawahOrdeBaru." http://www.bbc.co.uk/indonesian/ indepth/story/2008/01/080127_suhartoeconomy.shtml.Accessed 18 January 2014.

Indonesia Mengajar."Tentang Indonesia Mengajar.” https://indonesiamengajar.org/ faq/.Accessed on 19 January 2014.

SokolaRimba. "Program." http://www.sokola.org/program/.Accessed 19 January 2014.

Suyanto."KebijakanPemerintahtentang Pelaksanaan HakatasPen didikanDasar di Indonesia." http://dikdas.kemdikbud.go.id/application/media/file/ PAPARAN\%20DI\%20KEMKUMHAM\%20081110.pdf.Accessed 16 January 2014).

Tempo News. “AniesBaswedan: 'Indonesia Mengajar' TidakPolitis. " http://www. tempo.co/read/news/2013/09/26/078516917/Anies-Baswedan-IndonesiaMengajar-Tidak-Politis. Accessed 19 January 2014.

The Center for Economic and Social Rights."Education.” http://cesr.org/section. php?id=9.Accessed 13 January 2014. 